Doi: $\underline{\text { dx.doi.org/10.17921/2525-5320.2016.212-214 }}$

\title{
FÁBULA: O USO DE TECNOLOGIAS MÓVEIS EM SALA DE AULA E A AQUISIÇÃO DA SEQUÊNCIA NARRATIVA
}

Rejane Aguiar da Silva* - UTFPR

Evandro de Melo Catelão* - UTFPR

Palavras-chave: Fábula. Tecnologia. Ensino. Sequência narrativa.

\section{INTRODUÇÃO}

A utilização de tecnologias da informação e comunicação em sala de aula é uma significante mudança na concepção de ensino tradicional, uma vez que representa uma atualização do ambiente escolar às perspectivas interacionistas e do trabalho com os gêneros textuais. Nesse sentido, a concepção da linguagem admitida na aula de Língua Portuguesa toma a língua como fruto das interações sociais, sendo assim função da escola preparar o aluno para as diversas situações comunicativas, incluindo a necessidade em conceber um leitor multissemiótico para a ampla variedade de textos disponíveis atualmente.

O presente estudo trata de uma ação pedagógica efetiva em uma proposta de ensino e aprendizagem mediada por atividades na rede social Facebook e por recursos audiovisuais. Utiliza-se o gênero textual-literário fábula, observando, sobretudo, uma noção estrutural da sequência textual narrativa e como e como a atividade como um todo se constrói via mediação tecnológica.

O presente estudo objetivou apresentar uma proposta de trabalho docente de língua portuguesa com o uso de tecnologias móveis. Para tanto, a pesquisa em questão alicerça-se em pressupostos sócio-discursicas (ADAM, 2011; BRONCARKT, 2006) além de conceitos relativos aos multiletramentos, multissemioses e novas tecnologias viabilizados por Rojo (2012) e Xavier (2005).

\footnotetext{
*E-mail:rejaneaguiar@gmail.com

*E-mail:evandrocatelao@gmail.com
} 


\section{MATERIAL E MÉTODOS}

No que diz respeito à metodologia empregada, trata-se de uma proposta de intervenção pedagógica com base em projeto piloto qualitativo-interventivo. A pesquisa surge da necessidade em incorporar tecnologia e ambientes virtuais, tão presentes na vida do alunado, nas práticas pedagógicas da educação básica da rede pública de ensino. Dessa forma, pretende-se propor uma intervenção na qual a utilização de ferramentas tecnológicas intermedeiem o ensino e a aprendizagem. Ainda, para o desenvolvimento de habilidades e competências relativas ao gênero textual-literário fábula, há a mediação dos saberes com a criação de grupo de discussão na rede social Facebook, instuindo a divulgação dos saberes relativos ao domínio da sequência narrativa.

Sobretudo, mais que uma necessidade advinda das pesquisas teóricas, o exercício docente mediado por novas tecnologias é uma prática efetiva de multiletramento e, principalmente, uma correlação com um ensino interacionista e dialógico.

\section{RESULTADOS E DISCUSSÃO}

Espera-se com a aplicação do presente estudo consolidar o projeto de letramento e fornecer aos professores da rede um produto educacional que os direcione na tarefa de incluir a tecnologia no contexto escolar. Da mesma forma, intende-se promover em sala de aula e no grupo virtual a ambientação necessária para a construção do conhecimento, de competências de leitura e escrita, o letramento. A fábula, unidade comunicativa que possui como base sequência narrativa (possibilidade de lidar com elementos de produção do plano composicional narrativo), é um texto inicial ou deflagrador de atividades de recepção, leitura, interpretação e produção de diversos outros textos; diante deste percurso, as atividades visam o estabelecimento de uma didática que auxilie no processo de letramento à medida que privilegia o objetivo interativo e social presente nas representações textuais.

\section{CONCLUSÃO}

A implementação da atividade com união de vários planos teóricos possibilitou um amplo trabalho com as competências de leitura, análise composicional e 
produção de texto. A atividade de intervenção pedagógica, ligada à inserção de ferramentas tecnológicas para promover o ensino e aprendizagem em língua portuguesa, permitiu o desenvolvimento de capacidades no alunado além de práticas linguístico/discursivas ampliadas em outros gêneros, como o debate virtual.

\section{REFERÊNCIAS}

ADAM, J.-M. A linguística textual: introdução à análise textual dos discursos. São Paulo: Cortez, 2011.

BRONCKART, J.-P. Atividade de linguagem, discurso e desenvolvimento humano. Campinas: Mercado de Letras, 2006.

MARCUSCHI, L.A. Produção textual, análise de gêneros e compreensão. São Paulo: Parábola Editorial, 2008.

ROJO, R.; MOURA, E. Multiletramentos na escola. São Paulo: Parábola, 2012.

XAVIER, A.C. Letramento digital e ensino. In: Alfabetização e Letramento. CEEL, 2005. 